\title{
The development of ICT networks for South African schools
}

Two pilot studies in disadvantaged areas

\author{
Ingrid Siebörger ${ }^{1}$, Alfredo Terzoli ${ }^{1}$, and Cheryl Hodgkinson-Williams \\ 1 Computer Science Department, Rhodes University \\ Grahamstown. South Africa, 6139 [i.sieborger,a.terzoli]@ru.ac.za \\ WWW home page: http://www.cs.ru.ac.za \\ 2 Education Department, Rhodes University \\ Grahamstown. South Africa, 6139 chodgkinsonwilliams@gmail.com
}

\begin{abstract}
Information and Communication Technologies (ICTs) are increasingly considered valuable tools in education, promoting the development of higher cognitive processes and allowing teachers and learners access to a plethora of information. This paper reports on two pilot studies conducted in South Africa in proto-typical previously disadvantaged schools and their surrounding communities. Each pilot study deployed a local loop network within impoverished communities, connecting schools to one another and central services such as email and voice communications. The benefits of these networks were that teachers, learners and the local community had access to information, and communication and collaboration channels, providing potential test beds for investigating the use of computers as mind tools.
\end{abstract}

\section{Introduction}

Computers can be used in education as cognitive tools, or what Jonassen [1] calls Mindtools. For computers to be used as effective knowledge construction tools, networking of computers is essential, organizing them in local area networks (LAN) as well as connecting them to the Internet $[2,3,4]$. Cornu maintains that networking within the school will result in a change from the old form where knowledge circulated from the teacher to the learners, to a networked form where both learners and teachers are involved in the knowledge process and work together to generate knowledge and ideas via access to different resources such as libraries and the Internet [3]. This transformation is problematic in all institutions of formal learning, but is much more so in an environment such as the "previously disadvantaged" schools in South Africa where relations are steeply hierarchical and the separation between "teaching" and "learning" appears very strong. Besides, before we can realise the effects of the introduction of networked computers as tools of transformation, we need to build the physical infrastructure that is absent in large parts of South Africa. 


\section{Computer networks in South African schools}

The e-Education White paper [5], published in 2004, revealed that of the 6300 schools in the Eastern Cape $8.8 \%$ had computers, while only $4.5 \%$ deployed computers for teaching and learning purposes. The White paper expressed the objective that "Every teacher and learner in General and Further Education and Training must have access to an educational network and the Internet" [5, p 24]. In order for such a goal to be realised in the Eastern Cape there would need to be a substantial roll-out of ICT facilities to all the schools in the province.. An ICT rollout of this nature would require substantial financial assistance from the South African government and executed according to a carefully devised plan.

As there is not much information available about building computer networks within poorly resourced schools and communities, a pilot study was undertaken in two disadvantaged areas in the Eastern Cape. The first pilot takes place in the township of Grahamstown where the schools and the community are located in an peri-urban area, with basic general infrastructure, such as electricity, sanitation, telephone lines and road networks. The second pilot takes place in Dwesa, a deep rural, semi-marginalised community located on the Wild Coast in the former Transkei homeland of the Eastern Cape, which generally lacks basic facilities [11].

\section{The Grahamstown schools' ICT network}

Since its inception in 1998, the Rhodes University Telkom Centre of Excellence in the Computer Science Department has been conducting research into cost effective last mile Internet access solutions. One of the aims has been the identification of solutions that would be affordable and sustainable for previously disadvantaged schools. This research has included Digital Subscriber Lines (DSL) type connections [4, 6], WiFi (IEEE 802.11b/g) connections [4, 7, 8], and WiMAX (IEEE 802.16a) connections $[9,10]$, all with promising results. In the Grahamstown district in the Eastern Cape of South Africa, the Telkom CoE has built a local loop network which connects schools in the area to one another and shared resources and consists of these multiple technologies. This education local loop connects the schools to the Rhodes University network in such a way that each school is part of the greater Rhodes network. Each school then has access to central services housed on Rhodes campus such as email, Voice over IP (VoIP) and the Internet.

\section{The Dwesa ICT Network}

The Dwesa network employs WiMAX technologies only in local loop education network, which connects all the schools in the project to the shared Internet connection (via VSAT from Telkom) and to central services such as VoIP. This project is a joint venture between the Telkom CoEs at Rhodes University and the University of Fort Hare respectively. The original objective of the project was to develop and field-test the prototype of a simple, cost-effective and robust, integrated e-business/telecommunication platform, to deploy in marginalized and semimarginalized communities in South Africa, where a large number $(42.5 \%)$ of the South African population live. The project has evolved into an experiment on the adaptation of the Internet to rural areas in South Africa, based on the deployment of ICTs in schools, which together realise a distributed access network [12]. 


\section{Recommendations and lessons learned}

Both the networks in Grahamstown and Dwesa serve the school communities by firstly allowing them the opportunity to share commonly required resources, such as Internet connections and computer servers which run commonly required central services such as email and VoIP. Secondly the networks allow the teachers and learners to collaborate with one another through communication channels such as email, VoIP and chat programs. Thirdly, the schools, can share the cost of one or perhaps two technicians to support and maintain the network [4].

Thus far in both projects we have seen a keen uptake of ICTs among teachers and learners at the various schools. Besides the perception of a more critical engagement with knowledge among the various school actors, which is currently difficult to quantify, there have been noticeable practical effects of the introduction of ICT in Grahamstown and Dwesa First, learners involved in the Grahamstown project have entered into tertiary education institutions, still a very rare event here, with one notable student achieving a 90\% aggregate in his first year at Rhodes University. In addition, we have also begun to see the teachers use the ICT facilities to break down traditional hierarchies and to start to engage with computers as thinking tools. One teacher from Grahamstown used the ICT facilities to this end through the Global teenager project allowing learners to interact and learn with others from around the world. This eventually resulted in some of the learners winning the competition and being provided the opportunity to travel to Italy, an experience they would never otherwise have had. While, in Dwesa, one of the primary schools involved in the project has been extended into senior school and has been selected within the province to take part in a new e-learning programme.

Lessons learned throughout both pilot studies include the importance of champion teachers; ICT literate teaching staff and ICT training; good leadership by the principal; and community engagement at all levels, which seems to encourage ownership and lead to sustainability [13]. From the benefits we have seen in both the Grahamstown and the Dwesa schools we propose that a local loop networks be built in each district that will connect all schools in the district to one another and central services. Central services would include email, web services, domain name systems (DNS), proxy services, voice over IP (VoIP) services and videoconferencing.

\section{Conclusion}

In this paper we reported on the deployment of two local loop networks in South Africa in proto-typical, previously disadvantaged schools and their surrounding communities, one peri-urban and the other rural. Each network connected schools to one another and central services. The benefit of these networks is that teachers, learners and the local community have access to information, communication and collaboration channels. These network deployments will progressively expand; have constructed test beds for the potential exploration of using computers as Mind tools. Without the deployment of these networks and facilities to schools within South Africa we can not even begin to ask how ICTs can be used to engage learners in critical thinking. 


\section{References}

[1] D. H. Jonassen, C. Carr, and H.-P. Yueh, "Computers as Mindtools for Engaging Learners in Critical Thinking," TechTrends, vol. 43, no. 2, pp. 24-32, 1998.

[2] C.-C. Tsai, "A review and discussion of Epistomological Commitments, Metacognition, and Critical Thinking with suggestions on their enhancement in Internet-assisted Chemistry classrooms," Journal of Chemical Education, vol. 78, no. 7, p. 970.

[3] B. Cornu, World Year Book of Education 2004: Digital Technology, Communities and Education - Chapter2: Networking and collective intelligence for teachers and learners, A. Brown and N. Davis, Eds. Routledge Falmer, London and New York, 2004.

[4] I. Brandt, "Models of Internet connectivity for secondary schools in the Grahamstown Circuit," Master's thesis, Rhodes University, Jan. 2006.

[5] Department of Education, "White Paper on e-Education: Transforming learning and teaching through Information and Communication Technologies," Sept. 2004.

[6] G. A. Halse and A. Terzoli, "Open Source in South African Schools: Two Case Studies," in Highway Africa Conference, 2002. [Online]. Available: http://mombe.org/\%7Eguy/papers/highway-africa-2002/HALSE-Highway-Africa2002.pdf

[7] I. Brandt, A. Terzoli, and C. Hodgkinson-Williams, "Wireless Communication for Previously Disadvantaged Secondary Schools in Grahamstown, South Africa," in SATNAC 2005, Convergence - Can technology deliver?, Sept. 2005. [Online]. Available: http://ings.rucus.net/Brandt.pdf

[8] I. Brandt, A. Terzoli, and C. Hodgkinson-Williams, "Wi-Fi as a last mile access technology and The Tragedy of the Commons," ISBN 978-1-4020-6265-0 Innovative Algorithms and Techniques in Automation, Industrial Electronics and Telecommunications. Springer, 2007, pp. 175-180.

[9] I. Siebörger and A. Terzoli, "Field testing the Alvarion BreezeMAX as a last mile access technology," Sept. 2007.

[10] P. Beyleveld, "Deployment and Testing of WiMAX Wireless Network Technology," Computer Science Honours thesis, Rhodes University, Grahamstown, South Africa, 2006.

[11] R. Palmer, H. Timmermans, and D. Fay, From Conflict to Negotiation: Nature-based development on the South African Wild Coast. Pretoria: HSRCPress, 2002.

[12] M. Thinyane, L. Dalvit, A. Terzoli, and P. Clayton, "The Internet in rural communities: unrestricted and contextualized," Submitted to the International Conference on Distributed Computing and Internet Technology, Bangalore, INDIA, 2007

[13] C. Hodgkinson-Williams, I. Siebörger, and A. Terzoli, Enabling and constraining ICT practice in secondary schools: case studies in South Africa, International Journal of Knowledge and Learning, 3(2/3), p171 - 190. 